\title{
Sensibility of sugarcane cultivars to pre and post-emergence herbicides
}

Fernanda Maria Rodrigues Castro ${ }^{1}$

Adriano Teodoro Bruzi²

Marcos Machado Mourão ${ }^{3}$

Luiz Antônio de Bastos Andrade ${ }^{4}$

Adenilson Henrique Gonçalves ${ }^{5}$

José Airton Rodrigues Nunes ${ }^{6}$

\section{Abstract}

Chemical control is used to restrain the attack of weeds on cultivated crops in Brazil; however, the overuse of chemical products can cause damage to the crops. This study aimed to evaluate the phytotoxicity caused by pre-emergence (PRE) and post-emergence (POST) herbicides in sugarcane cultivars and their influence in agronomic and technological traits as well as to verify the existence of correlation between the herbicides effect and the measured traits. The experiment was carried out in a randomized complete block design with three replications, considering the factorial combination of five sugarcane cultivars and five control strategies, being four herbicides and one control. The sensitivity was evaluated at 30,60 and 90 days after application, through a scale of intoxication symptoms. The herbicides with active ingredients diuron + hexazinone and ametryn presented more phytotoxicity effect; the cultivars RB867515 and SP81-3250 showed greater toxicity symptoms when exposed to the agrochemicals. Plant height was the only trait influenced by the herbicides. It was observed a significant correlation between the trait number of stems and phytotoxicity effect.

Keywords: Saccharum spp. Cultivars. Phytotoxicity.

\section{Introduction}

Sugarcane planting is one of the earliest relevant economic activities in Brazil, being part of the national agribusiness as the third most important agricultural commodity (MAPA, 2017), playing a meaningful economic and social role. This importance is attributed mainly to its versatility and multiple uses as raw material to sugar and alcohol production; as electric energy by the sugarcane bagasse

1 Lavras Federal University (UFLA), Department of Agriculture, agronomist engineer/ PhD student in Plant Science. fefernandacastro@hotmail.com. University Campus - Caixa Postal 3037, Lavras, 37200-000, MG, Brazil.

2 Lavras Federal University (UFLA), Department of Agriculture, agronomist engineer/ professor/ PhD in Genetics and Plant Breeding, adrianobruzi@dag.ufla.br.

3 Agronomist engineer. marcos-mourao@hotmail.com.

4 Lavras Federal University (UFLA), Department of Agriculture, agronomist engineer/ professor/ PhD in Plant Science. laba@dag.ufla.br.

5 Lavras Federal University (UFLA), Department of Agriculture, agronomist engineer/ professor/ PhD in Weed Science. adenilsonhg@dag.ufla.br.

6 Lavras Federal University (UFLA), Department of Biology, agronomist engineer/ professor/ PhD in Genetics and Plant Breeding. jarnunes@dbi.ufla.br. 
burning; in natura for animal feed; as raw material in the manufacture of products as cachaça, syrup, brown sugar; also, to manufacture biodegradable plastics. According to the National Supply Company (CONAB, 2017), the production of sugarcane estimated for the $2017 / 18$ harvest is 647.6 million tons and the estimated harvest area is about 8.84 million hectares.

The weeds presence during the sugarcane (Saccharum spp.) and other crops development affect the yield, quality, harvest, transport and processing. Chemical management is the main method used to control invasive species due to its variety, for being an economical and high yielding method. Usually, the herbicides are selective and control weeds without affecting the main crop; however, the plants tolerance to a particular herbicide can be changed if it is used incorrectly (RIZZARDI; FLECK, 2004; TORRES et al., 2012).

The response of sugarcane cultivars to herbicides depends on biotic and abiotic factors. Thereby, it is important to evaluate the herbicide absorption by the plant as well as the effects of toxicity to validate doses, active ingredients and timing of application, which contribute for the plant to express its genetic potential (CERDEIRA et al., 2015; ODERO et al., 2015).

Several studies about weed control with systematic application of herbicides in pre and post-emergence conditions have demonstrated that, when the sugarcane is exposed to the action of agrochemicals, it can have morphological, physiological and technological changes (VIATOR; GRIFFIN; ELLIS, 2002; TORRES et al., 2012, ODERO et al., 2015).

Therefore, it is necessary to evaluate the relationship between the possible negative effects caused by the use of herbicides and the important economic traits of the crop. This becomes more complex because of the large amount of products available in the market and the different cultivars, considering the interaction between them may be very specific.

In this sense, this study aimed to evaluate the phytotoxicity caused by pre-emergence (PRE) and post-emergence (POST) herbicides in sugarcane cultivars and their influence in agronomic and technological traits; furthermore, it intended to verify the existence of correlation between the effect of the herbicides and the measured traits.

\section{Material and methods}

The experiment was carried out in the commercial area of sugarcane production of Cachaça Artesanal João Mendes company, in Perdões/MG city, located $842 \mathrm{~m}$ above sea level, $21^{\circ} 05^{\prime} \mathrm{S}$ and $45^{\circ} 05^{\prime} \mathrm{W}$. According to Köppen, the regional climate is $\mathrm{Cwb}$, with precipitation and temperature average of $1493.2 \mathrm{~mm}$ and $19.3^{\circ} \mathrm{C}$ (DANTAS et al., 2007).

Planting was carried out on November 2012, in a conventional cane-of-year system, in a randomized complete block design with three replications, considering the factorial combination of five sugarcane cultivars: RB867515, SP89-1115, SP80-1842, SP79-1011, SP81-3250 and four herbicides with different active ingredients (TABLE 1). The experimental plot consisted of four rows, 4 $\mathrm{m}$ long, with $1.4 \mathrm{~m}$ between rows and 12 sugar cane gems per linear meter, considering two central rows as effective area. Hand weeding was done for all plots. 
Table 1. Active ingredients, formulations, commercially recommended doses, commercial brands and timing of application in days after planting (DAP).

\begin{tabular}{l|c|c|c|c}
\hline \multicolumn{1}{c|}{ Herbicide } & Formulation ${ }^{1 /}$ & $\begin{array}{c}\text { r.d. }^{2} \text { / } \\
\text { (L or kg ha }\end{array}$ & Commercial Brand & $\begin{array}{c}\text { Application } \\
\text { (DAP) }\end{array}$ \\
\hline Ametryn & CS & 6.0 & Gesapax 500 & 8 (PRE) \\
Diuron thexazinone & WDG & 2.5 & Velpar K WG & 8 (PRE) \\
Clomazone & EC & 3.0 & Gamit & 8 (PRE) \\
MSMA & CS & 2.5 & Volcane & 30 (POST) \\
\hline
\end{tabular}

1/ CS - concentrated suspension, EC - emulsifiable concentrate and WDG- water dispersible granules;

2/ recommended dose.

Source: Elaborated by the authors (2016).

Herbicides were applied using a pressurized costal sprayer, which has $2 \mathrm{~m}$ long of herbicide application bar and four flat nozzle fan-type (Teejet XR 11002), spaced in $50 \mathrm{~cm}$, calibrated for the commercially recommended doses; the phytotoxicity evaluations were performed by two evaluators at 30, 60 and 90 days after application (DAA). It was used the EWRC (1964) scale of intoxication symptoms adapted by Rolim (1989), ranging from 0 (no damages) to 100 (total destruction) (TABLE 2).

Table 2. Percentage scale for evaluation of plants intoxication symptoms

\begin{tabular}{ccc}
\hline Scale & Description & Damages \\
\hline 0 & No effects & No damages \\
10 & & Slight discoloration and smaller plants \\
20 & Light effects & Discoloration and smaller plants \\
30 & More pronounced damages, but not lasting \\
40 & & Moderate damage, possibility of recovery \\
50 & Moderate effects & Lasting damage, difficult recovery \\
60 & & Lasting damage, no recovery \\
70 & & Severe damage with plants death \\
80 & Severe effects & Crops almost totally destroyed \\
90 & & Only few surviving plants \\
100 & Total effect & Total destruction \\
\hline
\end{tabular}

Source: Adapted from Rolim (1989).

Agronomic and technological traits of the treatments were measured one year after planting. The estimated traits were: 1) Stalks number per linear meter (SN): counting of total stalks dividing them by the plot area; 2) Mean stalk diameter of ten plants (SD): using a digital caliper rule; 3) plant height $(\mathrm{PH})$ : measured in meters from ground level to the insertion of the first leaf of ten plants, using measuring tape; 4) stalks mean mass (SMM): weighing of stalks/number of stalks; 5) tons of stalks per hectare (TSH): total weight of the plot area, in kilograms, converted into tons per hectare. 
At the harvest, samples of ten randomly selected stalks from each experimental plot were collected to determine the technological traits. At the Agronomic Institute of Campinas/Agribusiness Technology Agency of São Paulo - IAC/Apta, it was performed the analysis of: 1) apparent percentage of sucrose in sugarcane (Pol\% cane); 2) percentage of insoluble matter contained in sugarcane (Fiber\% cane); 3) percentage of soluble solids contained in sugarcane juice (Brix\% cane juice); 4) apparent purity (Purity\% cane); 5) total recoverable sugar (TRS) expressed as kilograms of sugar per 1,000 kilograms of sugarcane; 6 ) tons of Pol per hectare (TPH) (CONSECANA, 2006).

For joint variance analysis, it was adopted the split-plot in time model (STEEL; TORRIE, 1980), detailed in Equation 1:

$$
\mathrm{Y}_{\mathrm{ifjk}}=\mu+\mathrm{c}_{\mathrm{i}}+\mathrm{t}_{\mathrm{f}}+\mathrm{b}_{\mathrm{j}}+\mathrm{ct} \mathrm{t}_{\mathrm{if}}+\mathrm{e}_{\mathrm{ijf}}+\mathrm{p}_{\mathrm{k}}+\mathrm{e}_{\mathrm{jk}}+\mathrm{cp}_{\mathrm{ik}}+\mathrm{tp}_{\mathrm{fk}}+\mathrm{ctp} \mathrm{p}_{\mathrm{ifk}}+\varepsilon_{\mathrm{ijkf}}
$$

At which: $Y_{i f j k}$ : observation of the plot that received the $i$ cultivar, with the $f$ control, in the $j$ block, at the $k \mathrm{DAA} ; \mu$ : constant common to all observations; $\mathrm{c}_{i}$ : effect of cultivar $i$; $\mathrm{t}_{\mathrm{f}}$ : effect of control $f ; b_{\mathrm{j}}$ : effect of block $j$; $\mathrm{ct}_{\mathrm{if}}$ : effect of the interaction cultivar $i\left(\mathrm{c}_{\mathrm{i}}\right)$ and control $f\left(\mathrm{t}_{\mathrm{f}}\right) ; \mathrm{e}_{\mathrm{ijf}}$ : random error associated with interaction $c_{i}, t_{f}, b_{j}$ e $c t_{i f} ; p_{k}$ : effect of DAA $k ; \mathrm{cp}_{i k}$ : effect of the interaction cultivar $i\left(c_{i}\right)$ and DAA $k\left(p_{k}\right) ; \operatorname{tp}_{\mathrm{fk}}$ : effect of the interaction control $f\left(\mathrm{t}_{\mathrm{f}}\right)$ and DAA $k\left(\mathrm{p}_{\mathrm{k}}\right) ; \operatorname{ctp}_{\mathrm{ifk}}$ : effect of the interaction cultivar $i\left(c_{i}\right)$, control $f\left(t_{f}\right)$ and DAA $k\left(p_{k}\right) ; \varepsilon_{i j k f}$ : experimental error $(b)$.

Estimates of the phenotypic correlations measured between the traits were obtained according to Equation 2:

$$
r_{x y}=\operatorname{Cov}_{x y} / \sqrt{\mathrm{VxVy}}
$$

At which: Covxy estimation of phenotypic covariance between the variables $X$ and $Y ; \mathrm{Vx}, \mathrm{Vy}$ : are estimates of the mean phenotypic variances of the variables $X$ and $Y$, respectively.

Variance analysis and correlation were conducted through Genes software (CRUZ, 2006). For statistical significance, it was adopted the grouping of cultivar averages using the Scott-Knott's method (1974), with 5 and $1 \%$ of probability in the joint statistical analysis. As an estimate for the experimental precision, selective accuracy proposed by Resende and Duarte (2007) was adopted.

\section{Results and discussion}

Considering the joint statistical analysis of the days after herbicides application (DAA), differences were observed in relation to phytotoxicity for cultivars, DAA and interaction cultivars versus herbicides. Through the interaction, it was possible to verify there was a different response of the cultivars in relation to the action of the herbicides, being that phytotoxicity was more evidenced when using ametryn and diuron + hexazinone, applied to cultivars RB867515 and SP81-3250 (TABLE 3). There are reports in the literature about the interaction between cultivars and herbicides in sugarcane cultivation, which reinforces the premise that some cultivars may be more sensitive to some active ingredients than to others (BARELA; CHRISTOFFOLETI, 2006; ODERO et al., 2015). 
Table 3. Means of the phytotoxicity in sugarcane cultivars to the Amethryn and Diuron + Hexazinone herbicides.

\begin{tabular}{ccc}
\hline Cultivars & Ametryn & Diuron + Hexazinone \\
\hline RB867515 & $17.77 \mathrm{a}^{1 /}$ & $11.11 \mathrm{a}$ \\
SP81-3250 & $11.11 \mathrm{a}$ & $15.56 \mathrm{a}$ \\
SP80-1842 & $7.77 \mathrm{~b}$ & $4.44 \mathrm{~b}$ \\
SP79-1011 & $3.33 \mathrm{~b}$ & $1.11 \mathrm{~b}$ \\
SP89-1115 & $1.11 \mathrm{~b}$ & $2.22 \mathrm{~b}$ \\
\hline
\end{tabular}

${ }^{1 /}$ Means followed by the same letter in the column belong to the same group by the Scott-Knott's Test at $1 \%$ probability.

Source: Elaborated by the authors (2016).

By analyzing the evaluation times, the cultivars showed more expressive phytotoxicity rates at 30 DAA (TABLE 4). Monquero et al. (2011) verified that at 90 DAA no treatment with herbicide exhibited visual symptoms of phytotoxicity in sugarcane, probably due to the efficiency loss of the product influenced by environmental factors. According to Cerdeira et al. (2015), the estimation of herbicide bio concentration in sugarcane depends on its degradation in the environment, water availability, herbicide presence in soil solution and herbicide distribution in the plant.

Table 4. Means of the phytotoxicity effect on cultivars evaluated at 30, 60 and 90 days after herbicide application (DAA).

\begin{tabular}{cc}
\hline DAA & Means \\
\hline 30 & $14.93 \mathrm{a}^{1 /}$ \\
60 & $5.86 \mathrm{~b}$ \\
90 & $3.60 \mathrm{~b}$ \\
\hline
\end{tabular}

${ }^{1 / M e a n s}$ followed by the same letter belong to the same group by the Scott-Knott test at $1 \%$ probability.

Source: Elaborated by the authors (2016).

Considering the analysis of the phytotoxic effect for the agronomic and technological traits evaluation, it was observed a difference among the cultivars, which was already expected because they were genotypes with distinct traits. There was a different herbicide effect only for PH trait and there was no interference of the agrochemicals in the performance of the technological traits. There was also no interaction between cultivars and herbicides. Velini et al. (2000), Silva et al. (2014) and Sabbag et al. (2017), studying the selectivity of some herbicides in sugarcane cultivars, did not observe negative effects for phytotoxicity on the technological and agronomic evaluated parameters.

Analysis of the agronomic trait SN of the cultivars in the experiment showed an increment of stalks for the cultivars SP79-1011 (51.13) and SP81-3250 (51.06) (TABLE 5). According to Oliveira et al. (2007) and Andrade-Junior et al. (2017), this may be due to the genetic characteristics of each variety and to results of edaphoclimatic conditions favorable to the interaction genotype versus environment, promoting higher performance of these genotypes. The lower NS of the cultivars RB867515, SP80-1842 and SP89-1115 could be also due to the influence of the herbicides, because even if they have not showed a significant effect, these cultivars may have had a physiologic disturb when submitted to the active ingredient reducing tillering, same results found by Procópio et al. (2015) in their studies. 
Table 5. Means of the agronomic and technological traits: Stalks mean mass (SMM), stalks number (SN), plant height (PH), stalk diameter (SD), tons of stalks per hectare (TSH), tons of Pol per hectare (TPH), Brix\% cane juice (Brix), Purity\% cane (Purity) and total recoverable sugar (TRS $\mathrm{kg} \mathrm{t}^{-1}$ ), of the assessed cultivars.

\begin{tabular}{lccccc}
\hline Traits & RB867515 & SP80-1842 & SP79-1011 & SP81-3250 & SP89-1115 \\
\hline SMM & $1.43 \mathrm{a}^{1 /}$ & $1.09 \mathrm{~b}$ & $1.15 \mathrm{~b}$ & $1.15 \mathrm{~b}$ & $1.50 \mathrm{a}$ \\
SN & $37.80 \mathrm{c}$ & $46.06 \mathrm{~b}$ & $51.13 \mathrm{a}$ & $51.06 \mathrm{a}$ & $44.26 \mathrm{~b}$ \\
PH & $2.13 \mathrm{~b}$ & $2.38 \mathrm{a}$ & $2.01 \mathrm{c}$ & $2.16 \mathrm{~b}$ & $2.22 \mathrm{~b}$ \\
SD & $32.08 \mathrm{a}$ & $29.20 \mathrm{~b}$ & $28.53 \mathrm{~b}$ & $27.39 \mathrm{~b}$ & $32.82 \mathrm{a}$ \\
TSH & $78.34 \mathrm{~b}$ & $75.38 \mathrm{~b}$ & $85.45 \mathrm{a}$ & $86.11 \mathrm{a}$ & $83.70 \mathrm{a}$ \\
TPH & $12.53 \mathrm{~b}$ & $11.99 \mathrm{~b}$ & $13.57 \mathrm{a}$ & $13.56 \mathrm{a}$ & $14.63 \mathrm{a}$ \\
BRIX & $21.21 \mathrm{~b}$ & $21.22 \mathrm{~b}$ & $21.11 \mathrm{~b}$ & $20.91 \mathrm{~b}$ & $22.25 \mathrm{a}$ \\
PURITY & $90.80 \mathrm{~b}$ & $91.71 \mathrm{a}$ & $90.34 \mathrm{~b}$ & $90.64 \mathrm{~b}$ & $92.35 \mathrm{a}$ \\
TRS & $156.49 \mathrm{~b}$ & $155.32 \mathrm{~b}$ & $155.05 \mathrm{~b}$ & $153.97 \mathrm{~b}$ & $169.86 \mathrm{a}$ \\
\hline
\end{tabular}

1/Means followed by the same letter in the lines belong to the same group by the Scott-Knott's Test at $5 \%$ probability.

Source: Elaborated by the authors (2016).

The SMM trait had an inverse behavior compared to the SN trait, especially to the cultivars SP89-1115 (1.50) and RB867515 (1.43). This result corroborates the fact that too much stalks per hectare can result in narrow stalks, reducing the stalk unit mass. This was verified by the higher SD means of these varieties: SP89-1115 (32.82 mm) and RB867515 (32.08 mm). Sales et al. (2016) observed a mean diameter of $27.66 \mathrm{~mm}$ in the sugarcane maturation period in their studies.

The cultivars SP79-1011 (85.45 t ha-1), SP81-3250 (86.11 t ha-1) and SP89-1115 (83.70t $\mathrm{ha}^{-1}$ ) presented better performance to the trait TSH and to the trait $\mathrm{TPH}$, which is directly related to the TSH trait. Means ranged from $14.63 \mathrm{t} \mathrm{ha}^{-1}$ for cultivar SP89-1115 to $11.99 \mathrm{t} \mathrm{ha}^{-1}$ for cultivar SP80-1842 (TABLE 5). Sales et al. (2016) verified a TSH mean of $46.41 \mathrm{t} \mathrm{ha}^{-1}$ and TPH mean of $8.13 \mathrm{t} \mathrm{ha}^{-1}$ in their experiment.

Mean values of total soluble solids (Brix\% cane juice) showed all treatments were mature and ready for harvesting. The cultivar SP89-1115 obtained the highest value for Brix $\left(22.25^{\circ}\right.$ Brix $)$ (TABLE 5). The sugarcane industry considers that for a sugarcane to be processed, it must have at least $18^{\circ}$ Brix for both plant cane and ratoon (FRANCO et al., 2008; FERNANDES, 2000).

The purity means ranged from $92.35 \%$ for the cultivar SP89-1115 to $90.34 \%$ for the cultivar SP79-1011 (TABLE 5), being within the standards required for industrialization (FERNANDES, 2000).

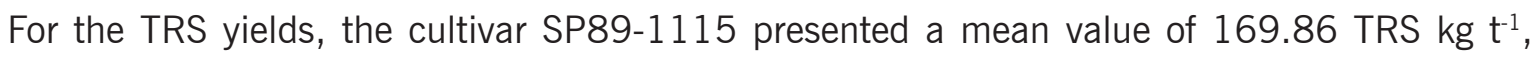
superior than other cultivars. Franco et al. (2008), evaluating the variety SP81-3250, obtained

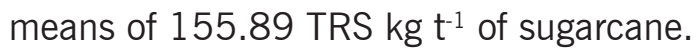

Through the herbicides analysis, it was possible to observe the active ingredients diuron + hexazinone and MSMA caused a decrease in the height final mean of the cultivars (TABLE 6), this effect may have been due to the action of this products and also due to the greater genotypes sensitivity. 
Table 6. Means of the herbicides effect on the plant height $(\mathrm{PH})$ agronomic trait.

\begin{tabular}{cc}
\hline Herbicides & PH \\
\hline Ametryn & $2.23 \mathrm{a}^{1 /}$ \\
Diruon + Hexazinone & $2.15 \mathrm{~b}$ \\
Clomazone & $2.24 \mathrm{a}$ \\
MSMA & $2.07 \mathrm{~b}$ \\
\hline
\end{tabular}

1/Means followed by the same letter belong to the same group by the Scott-Knott's Test at $5 \%$ probability.

Source: Elaborated by the authors (2016).

Through the phenotypic correlation study between the traits and the herbicides phytotoxicity effect, it was possible to observe a low and negative correlation for most of the traits, indicating a low influence of phytotoxicity on their phenotypic expression. The SN was the only trait that presented significant correlation, indicating the increase in the phytotoxicity symptoms may cause the reduction of the stalks number in the cultivation total area because they were negatively correlated (TABLE 7).

Table 7. Phenotypic correlation $\left(\mathrm{rf}_{\mathrm{xy}}\right.$ ) between the traits stalks mean mass (SMM), stalks number (SN), plant height (PH), stalk diameter (SD), tons of stalks per hectare (TSH), tons of Pol per hectare (TPH), Brix\% cane juice (Brix), Purity\% cane (Purity), total recoverable sugar (TRS $\mathrm{kg} \mathrm{t}^{-1}$ ), and the phytotoxicity effect of the assessed herbicides.

\begin{tabular}{|c|c|c|}
\hline \multicolumn{2}{|c|}{ Traits } & $r f_{x y}$ \\
\hline SMM & & 0.26 \\
\hline SN & & $-0.54^{*}$ \\
\hline $\mathrm{PH}$ & & -0.10 \\
\hline SD & & 0.12 \\
\hline TSH & x phytotoxicity & -0.18 \\
\hline TPH & & -0.34 \\
\hline BRIX & & -0.37 \\
\hline PUREZA & & -0.34 \\
\hline TRS & & -0.32 \\
\hline
\end{tabular}

* Significant at $5 \%$ probability, by T Test.

Source: Elaborated by the authors (2016).

\section{Conclusions}

The herbicides with active ingredients diuron + hexazinone and ametryn presented more phytotoxicity effect; the cultivars RB867515 and SP81-3250 showed greater toxicity symptoms when exposed to the agrochemicals. Plant height was the only trait influenced by the herbicides effect. It was observed a significant and negative correlation between the trait number of stems and phytotoxicity effect.

\section{Acknowledgements}

The authors thank the Federal University of Lavras - UFLA (Agriculture Department) for the constant support, and CAPES, CNPq and FAPEMIG for the financial support and scholarship. 


\section{Sensibilidade de cultivares de cana-de-açúcar a herbicidas pré e pós - emergentes}

\section{Resumo}

O controle químico é o mais utilizado para conter o ataque de plantas daninhas às principais culturas do Brasil, porém o uso excessivo pode acarretar danos às plantas de interesse. Com isso, objetivou-se avaliar a fitotoxicidade por herbicidas de pré-emergência (PRE) e pós-emergência (POST) em cultivares de cana-de-açúcar e sua influência em caracteres agronômicos e tecnológicos, além de verificar a existência de correlação entre o efeito dos herbicidas e os caracteres mensurados. 0 experimento foi conduzido no delineamento de blocos casualizados, com três repetições, considerando a combinação fatorial de cinco cultivares e cinco estratégias de controle, sendo quatro herbicidas e a capina manual. A sensibilidade foi avaliada aos 30, 60 e 90 dias após a aplicação, por meio de escala de notas de sintomas de intoxicação. Os herbicidas com os princípios ativos diuron + hexazinona e ametrina apresentaram maior efeito de fitotoxicidade; as cultivares RB867515 e SP81-3250 tiveram maiores sintomas de intoxicação quando expostas aos agroquímicos. A variável altura de planta foi a única influenciada pelo efeito dos herbicidas. Foi observada correlação significativa entre a variável número de colmos e o efeito de fitotoxicidade.

Palavras-chave: Saccharum spp. Cultivares. Fitotoxicidade.

\section{References}

ANDRADE JUNIOR, A. S. de; BASTOS, E. A.; RIBEIRO, V. Q.; SOBRINHO, C. A.; SILVA, P. H. S. da. Stalk yield of sugarcane cultivars under different water regimes by subsurface drip irrigation. Revista Brasileira de Engenharia Agrícola e Ambiental, Campina Grande, v. 21, n. 3, p. 169-174, 2017. Available in: http://dx.doi.org/10.1590/1807-1929/agriambi.v21n3p169-174. Access in: 29 Nov. 2017.

BARELA, J. F.; CHRISTOFFOLETI, P. J. Seletividade de herbicidas aplicados em pré-emergência da cultura da cana-de-açúcar (RB 867515) tratada com nematicidas. Planta Daninha, v. 24, n. 4, p. 371-378, 2006. Available in: http://dx.doi.org/10.1590/S0100-83582006000200022. Access in: 29 Nov. 2017.

CERDEIRA, A. L.; PARAÍBA, L. C.; QUEIROZ, S. C. N. de; MATALlO; M. B.; FRANCO, D. A. S.; FERRACINI, V. L. Estimation of herbicide bioconcentration in sugarcane (Saccharum officinarum L.). Ciência Rural, Santa Maria, v. 45, n. 4, p. 591-597, 2015. Available in: http://dx.doi. org/10.1590/0103-8478cr20120466. Access in: 29 Nov. 2017.

COMPANHIA NACIONAL DE ABASTECIMENTO (CONAB). Acompanhamento da safra brasileira, cana-de-açúcar. Monitoramento agrícola - safra 2017/18: primeiro levantamento, v. 4, n. 1, abr. 2017. Available in: https://www.conab.gov.br/info-agro/safras/cana/boletim-da-safra-de-cana-deacucar/item/download/1208_70e861d4ccc431c8aeb5e9b68d25d2f5. Access in: 16 May 2017. 
CONSELHO DOS PRODUTORES DE CANA-DE-AÇÚCAR, AÇÚCAR E ÁLCOOL DO ESTADO DE SÃO PAULO. Manual de Instruções; 5 ed. Piracicaba-SP: CONSECANA-SP, 2006. 112 p.

CRUZ, C. D. Programa Genes - Biometria. 1 ed. Viçosa, MG: Editora UFV, 2006. v.1, 382 p.

DANTAS, A. A.; CARVALHO, L. G.; FERREIRA, E. Classificação e tendências climáticas em Lavras, MG. Ciência e Agrotecnologia, v. 31, n. 6, p. 1862-1866, 2007. Available in: http://dx.doi. org/10.1590/S1413-70542007000600039. Access in: 4 jan. 2017.

EUROPEAN WEED RESEARCH COUNCIL (EWRC). Report of the $3^{\text {rd }}$ and $4^{\text {th }}$ meetings of EWRC Committee of methods in Weed Research. Weed Res., Oxford, v. 4, n. 1, p. 88, 1964.

FERNANDES, A. C. Cálculos na Agroindústria da Cana-de-açúcar; 3 ed. Piracicaba: STAB - Sociedade dos Técnicos Açucareiros e Alcooleiros do Brasil, 2011. 416p.

FRANCO, A.; MARQUES, M. O.; MELO, W. J. de. Sugarcane grown in an Oxisol amended with sewage sludge and vinasse: nitrogen contents in soil and plant. Scientia Agricola, v. 65, n. 4, p. 408-414, 2008. Available in: http://dx.doi.org/10.1590/S0103-90162008000400013. Access in: 16 May 2017.

MINISTÉRIO DA AGRICULTURA, PECUÁRIA E ABASTECIMENTO (MAPA). Secretaria de Relações Internacionais do Agronegócio - Balança Comercial do Agronegócio-Março/2017. Available in: www. agricultura.gov.br/noticias/exportacoes-do...us-8.../nota-marco-2017.docx. Access in: 29 Nov. 2017.

MONQUERO, P. A.; BINHA, D. P.; INÁCIO, E. M.; SILVA, P. V. da; AMARAL, L. R. do. Seletividade de herbicidas em variedades de cana-de-açúcar. Bragantia, v. 70, n. 2, p. 286-293, 2011. Available in: http://www.scielo.br/pdf/brag/v70n2/06.pdf. Access in: 29 Nov. 2017.

ODERO, D. C.; FERNANDEZ, J. V.; SANDHU, H. S.; SINGH, M. P. Response of Energycane to Preemergence and Postemergence Herbicides. Weed Technology, v. 29, n. 4, p. 810-820, 2015. Available in: http://www.bioone.org/doi/full/10.1614/WT-D-15-00033.1. Access in: 4 Jan. 2017.

OLIVEIRA, R. A.; OLIVEIRA, R. A. de; DAROS, E.; ZAMBON, J. L. C.; WEBER, H.; IDO O. T.; BESPALHOK-FILHO, J. C.; ZUFFELLATO-RIBAS, K. C.; SILVA, D. K. T. da. Área foliar em três cultivares de cana-de-açúcar e sua correlação com a produção de biomassa. Pesquisa Agropecuária Tropical, v. 37, n. 2, p. 71-76, 2007. Available in: https://www.revistas.ufg.br/pat/article/view/1672. Access in: 4 Jan. 2017.

PROCÓPIO, S. O.; SILVA, A. A. da; FERREIRA, E. A.; SILVA A. F. da; GALON, L. Weed management. In: SANTOS, F.; BORÉM, A.; CALDAS, C. Sugarcane Agricultural Production, Bioenergy and Ethanol. London, England: Academic Press, 2015. p. 133-159.

RESENDE, M. D. V.; DUARTE, J. B. Precisão e controle de qualidade em experimentos de avaliação de cultivares. Pesquisa Agropecuária Tropical, v. 37, n. 3, p. 182 - 194, 2007. Available in: https:// www.revistas.ufg.br/pat/article/download/1867/1773/. Access in: 29 Nov. 2017.

RIZZARDI, M. A.; FLECK, N. G. Dose econômica ótima de acifluorfen + bentazon para controle de picão-preto e guanxuma em soja. Planta Daninha, v. 22, n. 1, p. 117-125, 2004. Available in: http://dx.doi.org/10.1590/S0100-83582004000100015. Access in: 4 Jan. 2017. 
ROLIM, J. C. Proposta de utilização da escala EWRC modificada em ensaios de campo com herbicidas. Araras: IAA/PLANALSUCAR. Coordenadoria Regional Sul, 1989. 3 p.

SABBAG, R. S.; MONQUERO, P. A.; HIRATA, A. C. S.; SANTOS, P. H. V. dos. Crescimento inicial de mudas pré brotadas de cana-de-açúcar submetidas à aplicação de herbicidas. Revista Brasileira de Herbicidas, v. 16, n. 1, p. 38-49, 2017. Available in: http://dx.doi.org/10.7824/rbh.v16i1.481. Access in: 16 May 2017.

SALES, L. R.; CESAR, L. E. V.; BRUZI, A. T.; NUNES, J. A. R.; ANDRADE, L. A. de B., LOPES, M. F. Seleção de cultivares de cana-de-açúcar potenciais para o município de Lavras - sul de Minas Gerais. Revista Agrogeoambiental, v. 8, n. 1, p. 97-109, 2016. Avalaible in: http://dx.doi. org/10.18406/2316-1817v8n12016788. Access in: 4 Jan. 2017.

SCOTT, A. J.; KNOTT, M. A. A cluster analysis method for grouping means in the analysis of variance. Biometrics, v. 30, n. 3, p. 507-512, 1974. Available in: https://www.ime.usp.br/ abe/lista/ pdfXz71qDkDx1.pdf. Access in: 4 Jan. 2017.

SILVA, A. F. da; GALON, L.; CONCENCO, G.; ASPIAZÚ, I.; FERREIRA, E. A.; TIRONI, S. P. Sugarcane cultivars present differential susceptibility to herbicides ametryn and trifloxysulfuronsodium. Australian Journal of Crop Science, v. 8, n. 6, p. 965, 2014. Available in: https://www. embrapa.br/busca-de-publicacoes/-/publicacao/1003180/sugarcane-cultivars-present-differentialsusceptibility-to-herbicides-ametryn-and-trifloxysulfuron-sodium. Access in: 16 May 2017.

STEEL, R. G. D.; TORRIE, J. H. Principles and procedures of statistics: a biometrical approach; 2 ed. New York: McGraw-Hill Book Company, 1980.

TORRES, L. G.; FERREIRA, E. A.; ROCHA, P. R. R.; FARIA, A. T.; GONÇALVES, V. A.; GALON, L.; SILVA, A. F.; SILVA, A. A. Alterações nas características fisiológicas de cultivares de cana-de-açúcar submetida à aplicação de herbicidas. Planta Daninha, Viçosa-MG, v. 30, n. 3, p. 581-587, 2012. Available in: http://dx.doi.org/10.1590/S0100-83582012000300014. Access in: 16 May 2017.

VEliNI, E. D.; MARTINS, D.; MANOEL, L. A.; MATSUOKA, S.; TRAVAIN, J. C.; CARVALHO, J. C. Avaliação da seletividade da mistura de oxyfluorfen e ametryne, aplicada em pré ou pós-emergência, a dez variedades de cana-de-açúcar (cana-planta). Planta Daninha. v. 18, n. 1, p. 123-134, 2000. Available in: http://dx.doi.org/10.1590/S0100-83582000000100012. Access in: 4 Jan. 2017.

VIATOR, B. J.; GRIFFIN, J. L.; ELLIS, J. M. Sugarcane (Saccharum spp.) response to Azafeniden applied Preemergence and Postemergence. Weed Technology, v. 16, n. 2, p. 444-451, 2002. Avalaible in: http://www.bioone.org/doi/full/10.1614/0890-037X\%282002\%29016\%5B0444\%3A SSSRTA\%5D2.0.CO\%3B2. Access in: 4 Jan. 2017.

Received: June 26, 2017

Accepted: December 12, 2017 